\title{
Recognition in the Communication Processes of Diverse Young the Experience of Living in a Park in the City of Cali*
}

\author{
Mónica Marión Cataño ${ }^{1,2}$ \\ ${ }^{1}$ Department of Language and Communication, Pontificia Universidad Javeriana, Cali, Colombia \\ ${ }^{2}$ CINDE-Universidad of Manizales, Manizales, Colombia \\ Email: mmarion@javerianacali.edu.co
}

Received 23 February 2015; accepted 25 March 2015; published 26 March 2015

Copyright (C) 2015 by author and Scientific Research Publishing Inc.

This work is licensed under the Creative Commons Attribution International License (CC BY). http://creativecommons.org/licenses/by/4.0/

(c) (7) Open Access

\section{Abstract}

Artisan Park La Loma de la Cruz, is a park located in a suburb of the city of Cali, a place where different groups converge youth from youth cultures. The park is a place for meeting, socializing, communication practices through which young people interact and build relationships. The park is set up as a stage of "coexistence" in which rockers, punks, emos, skaters and members of the LGBTI community stay together and share the same dwelling place (Figure 1). In the worlds of life of these young people, the words in different languages are a part of his being and his feelings, hence the affectations of joy and sadness, as defined by Spinoza $(1980)^{1}$, are a way of weaving links and establish relationships communication. It is also possible to identify forms of recognition, Honneth's way, recognition of love and solidarity ${ }^{2}$. These forms of recognition collide when young people, relate to the adult world, in the park, are made by artisans, police and neighbors. From the adult world, the form of contempt is evident in the rejection of the young by their expressions, especially those with expressing his affectations manifest. If young people recognize the existence of other people, as well as their own differences in the way they think, if they recognize the action in their own inter-subjective relationships and in the same way they construct a "we", we would be spectators of new ways of being together; of ethical and political linking which go through new ways of living together and in which the sense and the shared meaning of life are negotiated that show a way of understanding in communication.

\footnotetext{
*This paper emerges from ongoing research entitled: communication, coexistence and ways of being together diverse youth in a park in the city of Cali, which is performed as a doctoral thesis in social sciences, children and youth in the youth line, cultures and powers. The work is performed under the direction of Dr. Germán Muñoz Gonzáles. A version of this text was presented at the Second Congress of Social Sciences of the Universidad Pontificia Bolivariana.

${ }^{1}$ In the third part, Ethical demonstrates according to the geometric order. Spinoza describes the nature and origin of the affections.

${ }^{2}$ Honneth identifies three forms of recognition: love, law and solidarity. Relacones among young people that inhabit the park, the first and the third are identified.
}

How to cite this paper: Cataño, M. M. (2015). Recognition in the Communication Processes of Diverse Young the Experience of Living in a Park in the City of Cali. Advances in Journalism and Communication, 3, 33-38.

http://dx.doi.org/10.4236/ajc.2015.31004 


\section{Keywords}

\section{Recognition, Interaction, Intersubjectivity, Involvement, Communication}

\section{On Key Concepts: Recognition, Interaction and Intersubjectivity}

The notion of recognition was given by $\mathrm{Hegel}^{3}$ in the late eighteenth century when he undertook the project of reconstruction of the evolution of human morality although Hobbes and Rousseau had made approaches to term.

Hobbes argued that men were dominated by the need to obtain a degree of recognition and honor and Rousseau said that was just the appearance of the desire for social appreciation when men began to lose confidence in them. The objectives of Hegel, in his early writings, were designed to explain how the experience of recognition could have the effect of a breakthrough in the field of moral because it was necessary that there was reciprocity between acquisition intersubjective self-awareness and moral development of societies (Hegel, 1985). Hegel placed three patterns of recognition were the foundation for the recognition Honneth raised as the new normative order is imposed on the elimination of inequality, which has long been central to the ideal of justice. Dignity and respect are the new categories from which you can address the prevention of humiliation and contempt.

The starting points for Honneth to present a conception of social morality from recognition are moral damages which are experienced as injustice. Physical damage constitutes a moral injustice if the affected person sees in it a performance that intentionally disparages an essential aspect of their being (Honneth, 2010: p. 24). Honneth identifies three forms of contempts which underlie them three ways recognition. The first form of contempt constitutes torture or rape; the second, the disenfranchisement and social exclusion and the third, the social degradation. The forms of recognitions of each form of contempt are love, legal recognition and solidarity respectively (Table 1). Also, with every form of recognition self-confidence, self-respect and self-esteem are activated.

The three recognition models, Honneth argues, the formal conditions of interaction relationships within which men can see secured his dignity or integrity are established.

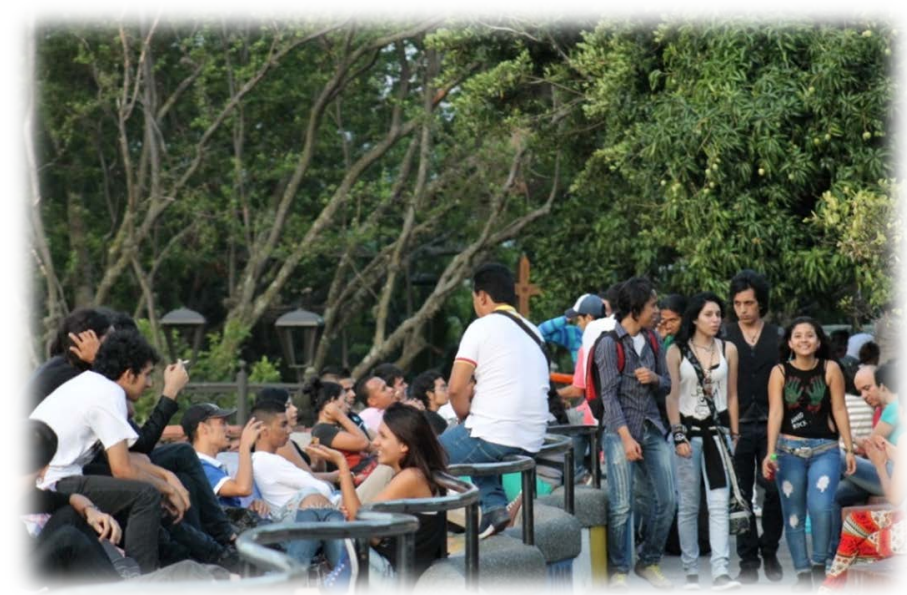

Figure 1. Together; f: 4.5, V: 1/200, ISO: 2500 by Mónica Marión Cataño O.

Table 1. Recognition and contempt forms.

\begin{tabular}{ccc}
\hline Form of contempt & Shape recognition & Positive attitude \\
\hline Violation & Love & Self-confidence \\
Deprivation/exclusion & Rights & Self-respect \\
Social degradation & Solidarity & Esteem \\
\hline
\end{tabular}

Source: own elaborated.

${ }^{3}$ The first approache to recognition was made by Hegel in Book IV of the Phenomenology of Spirit when it comes to self-consciousness. 
The recognition implies that the interaction takes place in relations among and with others so that intersubjectivity appears as a condition. Intersubjectivity is the process whereby knowledge with the world of life and that knowledge emerge from the consciousness we have of all things from the point of view that is shared in everyday life are shared, i.e. from subjectivity.

From the phenomenological sociology, Schütz (1993), undertook to clarify the meanings are socially constructed in interaction networks. Takes the ideas of Husserl as he worked on understanding the world of the living and Weber, who defines social function of a relationship behavior between two or more people and the concept of action as conduct which is awarded a subjective meaning, likewise, share the idea of understanding the function of sociology therefore "the world of everyday life is not a private world but shared with my peers" (Schütz, 1993: p. 5).

Everyday life is expressed in relations between social actors among themselves and in how they build and understand social reality, likewise, intersubjectivity is the foundation that allows the existence of the world of life as meaningless horizon where daily life it is a region of sense.

Direct communication processes are unthinkable without the inter-relationships and interactions therein. Both the phenomenological sociology and symbolic interactionism have contributed in building the field of communication as noted by Galindo (2008) when he argues that the interactions are central communications studies which detaches to communication from the traditional approach that places the study of media as their main object of study.

Interaction refers to the ability of people to see, hear, feel, what the theory of feelings would be involved in something and that something can be another human being, a concept, myself, a process, a situation other feeling (Heller, 1999). These actions, sensitive, are ways of relating to the world and the way meaning is produced.

The interaction model is based on two people to be co-presence, again and try to handle the information or they already have. This requires some degree of control over expressive behavior, so that the individual project a "definition of the situation" to appear before, or others and maintain a facade of consensus-agreement regarding the desirability of avoiding a conflict manifest definition of the situation (Goffman in Lara and Reyes, 2010: p. 8, 9).

The interaction has been studied from the symbolic interaction where there is concern about the interpretation that actors give to the symbols that emerge in the interactions. People act on the meanings that give objects and situations around them and meanings come from the interaction that an individual maintains with other actors, with the meanings which are used in the rendering process (Rizo, 2011).

Communication processes occur in the encounter and interaction with another or others and it is through this meeting where subjects acquire reflective capacity to project an image if before the other, to others and, in turn, created images other.

\section{Young People in the Experience of Inhabit}

The craft park becomes a scene of meeting of young diverse. The diversity resides young models, among other characteristics, their cultural preferences so congregate in groups so that youth cultures are like punks, rockers, skaters, metalheads, jugglers, skinheads, hippies. Some of them clustered in groups like Botas Negras, Malabarte, Pirrurias, Jaguar Punks or bands. Come on Thursday, Friday and/or Saturday but the day of the greater participation of young park is Friday the assistance of the LGBTI community (Figure 1).

This allows the definition of youth cultures is, in most groups, their musical preference, either because they are gang members or because their cultural consumption is crossed by the music genre you listen to. Here, as noted Muñoz, it is clear "the preeminent place of music in the lives of youth cultures; we can say that this happens in the lives of most young men/women. The power that holds the music, the atmosphere it creates, the collective sensibility that triggers involve multiple functions: it produces a particular kind of knowledge, some convivial openness to others, an aesthetic feeling, a desire to affirm life” (Muñoz, 2006: p. 97)

Here comes the punk culture, skinhead occasionally, rastafarian, emos and most prevalent here is the LGBT community, and those who want to come here to take your glass of wine and talk.

(Fulano, punk, 20)

At 5:00 pm starts the arrival of young people to the park and begin to move in parallel to the stalls selling handicrafts, decorative items and jewelry terraces. According to the time of arrival, are located at the north end of the park to the noise of the activities planned in the central square does not interfere with their activities while they are together and when the meeting takes place, begins the chain of rituals interaction (Collins, 2009) that 
begins with the particular way of greeting set within the group and with relatives:

The greeting: clap sticks... and this (hand) slides, and received with a closed fist. What do you mean? I do not know well, usually interpret it as saying you're good with me!

(Mateo, rockero, 18)

Since the meeting of bodies, where the senses are tuned: sight, smell, skin and actions performed on it, touch, kiss, hug, smile exchange, immediate situational emotions, joy, joy that have to occur young interacting actions which subsequently; are the affections, especially of joy and affection for an external cause (the meeting) that derives its power of acting in satisfaction (Spinoza, 1980).

The park is a place to live, to be, young people feel that the place allows them to be, as defined by Heidegger (1986: p. 67) "I am, that is, in turn, dwell, I stay..."

...is a place where I come to relax and be out of my house drawing, watching television, internet and sleeping do not know. It's like a place of relaxation, socialization to be good, "recocha",, teasing.

(Andrea, 17)

To me it means the place where I can rest, where I can be free somehow clear freedom does not mean damage or anything like that, the fact is that I'm fine, it's nice.

(Damián, metalhead, 17)

Means freedom... this park, I think the main thing is also quiet because there is nothing contrary, one feels at home with his family

(Gustavo, LGBTI community, 19)

In the experience of inhabiting the park, young people construct a sense of place, their bodies are affected by emotions, by encounters which expressed through the languages that can be expressed. Not that being and staying in a place, is that the place is the meeting itself (Yory, 2007: p. 66).

The park is a place where multiple exchanges occur. In the inter-relationships among youth, affective exchanges are frequent and the expression of their feelings and emotions but there are also trade as the park is a stage of making and selling crafts and other goods marketing. Craftsmen and merchants organized in their production and exhibition stalls are in tension with the youth because they claim that their presence and youthful expressions, have alienated buyers. The tension is accentuated with some neighbors to question and disagree with the appropriation of the place made the young. They argue that the police, who has a Centre for Immediate Care-CAI in the center of the park, has not acted properly to avoid concentration and congregation of young people. Artisans, merchants, neighbors, police officers and managers from the state park management, constitute the adult world so that tensions between the world of youth with the adult world are inevitable.

Since the relationship with the market, young people approve and celebrate the park is for the exchange of cultural goods. It is not only the manufacture, sale marketing of objects but of cultural activities and processes that are programmed into it: poetry, Wednesdays; Andean dances, Thursdays; storytellers or artistic presentations scheduled from the Ministry of Culture, Friday and, Film the on park on Saturdays. Young people do not participate as spectators or practitioners of the above activities but feel a great attraction for the cultural dynamics of the park. For some adults, the presence of young people is not pleasant. His appearance, clothes and accessories, musical tastes and practices associated with consumption of liquor, cigarette and illicit substances as well as expressions of affection, especially from the LGBTI community, creates them repudiate.

The park is very... well, there's a lot of culture.

(William, 16)

I am not... agree is with some artisans who want to steal the park, wrote there (points to wall) that says "no shows Friendly obscene" that placed him recently artisans. With them is not us take so well to say (Figure 2). (Diana, LGBTI, 18)

There are police officers, very few who are respectful lead one for good but there are others who see it as a criminal, treat bad one, because there is no verbal aggression and abuse of authority. (Andrea, 17 years)

...Because many people do not like coming to see that other people because they fear and panic (Luis, artisan, bamboo objects and seeds)

Today and Friday was damaged, because is some gay people are people of the LGBT group lesbianism is seen, and this sometimes comes educated people coming with their children and go to see a show two there kissing women get scared and go. (Jose, artisan leather sandals)

${ }^{4}$ Recocha in Spanish is a similar expression to fuck young, annoy, enjoy. 


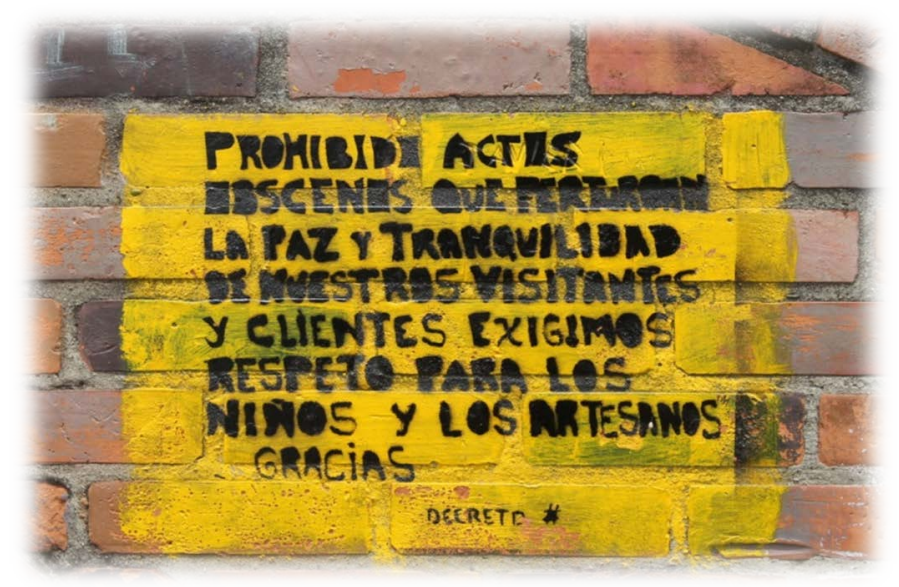

Figure 2. Forbidden love; f: 9, V: 1/200, ISO: 100 by Mónica Marión Cataño O.

\section{Love and Solidarity as Forms of Recognition}

Interactions that arise in the inter-relationships between young people and following the "patterns of intersubjective recognition" with Honneth (1997: p. 114) we can say that love is a form of social integration among them, their emotional commitment present in the reciprocal relations of love or friendship constitutes a form of recognition that is attached to the physical existence of people of special interest or feelings of love they profess. This type of affective recognition gives young emotional security and facilitates the externalization of their own feelings about one another, with their peers. The attitudes of sympathy, attraction and affection linked to the joy being and being with others provide a "moral particularism, which cannot be dissolved by any internal generalization" (Honneth, 2009: p. 26). Love relationships are not only limited to those relationships mediated by romantic love or eroticism but the basic relationships of filial and brotherly love. This occurs on the collective experience of inhabiting the park by young and only among themselves, but when it comes to analyzing the tension generated among the youth with the adult world, appears in the form of abuse scorn, characterized by demonstrations against verbal attacks and accusations by gender and sexual orientation of some young people.

Homophobia, Lesbophobia as feelings of rejection by adults reflects the form of contempt which is just opposite to love, so that the first form of recognition, love and friendship that strengthens self-confidence in the subject moves a form of contempt in relationships between young craftsmen, young-neighbors, youth-police.

The other form of recognition present in the relationships among youth constitutes solidarity as a community value. Between youth groups and cultures ratio solidarity approval and an appreciation for individual life forms developed (Honneth, 2009: p. 28) in which respect for difference, valuing different cultural practices by diverse young and no solidarity to support the cause of a group that sometimes acquires shades of complicity:

The park is a place to meet and have different types of view, not only in the downstairs area but also in the upstairs area. We have the support of some of the rockers as we call them here, they defend us from people who want us to take, some people are super nice.

(Diana, LGBTI, 18)

Some groups made up of young people in park accompany social and political causes of others, as happens with the collective Black Boots marches that accompanied the LGBTI community in which fighting for their rights, such as the March for Gay Pride.

A previous shape recognition, solidarity, becomes his form of opposition or scorn, indignity, disgrace, that the tensions of youth with the adult world are evident in the constant accusations and called the authority for the preservation of "order".

These two forms of recognition and contempt, plausible relationships between youth and adult worlds pose challenges to continue on the path leading to rules of social theory to integration. Affective feelings associated with the contempt note decay pathologies of reason, invisibility occur in both worlds. Both the Status of Youth Citizenship and Public Policy for the LGBTI Community constitute policy and legislative frameworks that stress the importance of recognizing the difference from a rights perspective however there by the state programs to disclose normative or plans related to the realization and recognition of young people there ignorance about the 


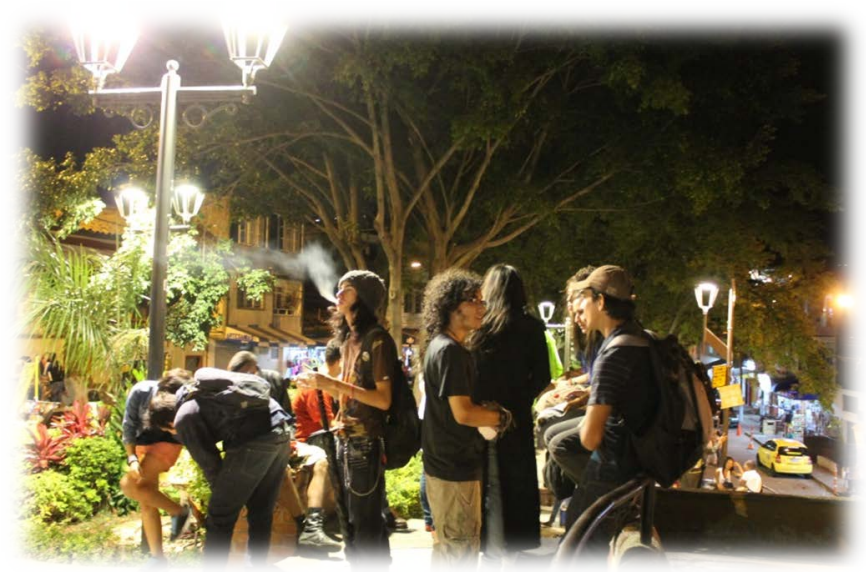

Figure 3. At night being, f: 3.5, V: 1/15, ISO: 3200 by Mónica Marión Cataño O.

legal issues. While youth is a modern "invention," the youth condition that bypasses a biological issue-age range, are clamoring to be recognized in its social, political and esthetic.

There are thousands of youngsters who live in the city and another hundreds who are looking for a place to affirm themselves with other young people (Figure 3). Communication processes among youth that inhabit the park are mediated by expression across languages, for aesthetic, for laughter and for the affections without ignoring the conflicts that emerge in the interaction between themselves. The truth is that the collision with the adult world and what it represents is imminent. The market, the state, the mechanisms of authority and control around the scene of interaction of young people are present in their subjectivities. Young people are in that place because they are allowed to be there and because there are no other places that are not influenced by the market where they can be and exist. The city is not designed for them, so they are appropriating public places for themselves, to be and to feel included. Likewise, they are generating circuits and routes by transiting appropriating places like expression of being and feeling.

\section{References}

Collins, R. (2009). Cadenas de rituales de interacción. Anthropos editorial, Barcelona.

Galindo, J. (2008). Comunicación, ciencia e historia. Fuentes científicas históricas hacia una comunicología posible. McGraw Hill Interamericana, Madrid.

Hegel, G. (1985). Fenomenología del espíritu. Fondo de cultura económica, Sexta reimpresión, Madrid.

Heidegger, M. (1986). Ser y tiempo. Edición digital, en Heidegger en castellano: Edición digital de. http://www.philosophia.cl http://www.heideggeriana.com.ar

Heller, A. (1999). Teoría de los sentimientos. Ediciones Coyoacán, México.

Honnet, A. (2009). Reconocimiento y menosprecio. Sobre la fundamentación normativa de una teoría social. Editorial Katz, Barcelona.

Honneth, A. (1997). La lucha por el reconocimiento. Por una gramática moral de los conflictos sociales. Ed. Grijalbo Mondadori, Barcelona.

Lara, A. \& Reyes, M. (2010). Erving Goffman: Microinteracción y espacio social.

Muñoz, G. (2006). La comunicación en los mundos de vida juveniles. Hacia una ciudadanía comunicativa. Tesis doctoral en Ciencias sociales, Niñez y Juventud. CINDE-Universidad de Manizales.

Rizo, M. (2011). De personas, rituales y máscaras. Erving Goffman y sus aportes a la comunicación interpersonal. EN: Revista Quórum Académico, Vol 8, No. 15. Universidad de Zulia. Venezuela.

Schütz, A. (1993). La construcción significativa del mundo social. Editorial Paidós, Barcelona.

Spinoza, B. (1980). Ética demostrada según el orden geométrico. Ediciones Orbi, Barcelona.

Yory, C. (2007). Topofilia o la dimensión poética del habitar. Editorial Pontificia Universidad Javeriana, Bogotá, Segunda Edición. 